\title{
Effect of Biochar Application and Arbuscular Mycorrhizal Inoculation on Root Colonization and Soil Chemical Properties
}

\author{
Sunusi Abdu Yusif*a and Michael Olajire Dare ${ }^{\mathrm{b}}$ \\ ${ }^{a}$ Department of Soil Science and Agricultural Engineering, Faculty of Agriculture, Usmanu Danfodiyo \\ University, Sokoto. P.M.B. 2346, Sokoto, Nigeria. \\ ${ }^{\mathrm{b}}$ Department of Soil Science and Land Management, College of Plant Science and Crop Production, Federal \\ University of Agriculture Abeokuta, P.M.B. 2240, Ogun State, Nigeria. \\ *Corresponding author email: yusif.sunusi@udusok.edu.ng, yusifsunusiabdu@gmail.com
}

Received: 22 February 2017 / Accepted: 25 February 2017 / Published: 26 February 2017

\begin{abstract}
Field experiment was carried out in 2013 and 2014 to investigate the effects of biochar application and arbuscular mycorrhizal (AM) inoculation on AM root colonization and selected soil chemical properties of two tomato genotypes. The experiment was laid out in a split-split plot arrangement with two tomato genotypes in the main plots, five rates of biochar applied in the sub plots and two levels of AMF inoculation in the sub-sub plots. Data were subjected to analysis of variance and significant means separated using Duncan's Multiple Range Test $(\mathrm{P}<0.05)$. The results indicated that mycorrhizal inoculation had little or no influence on $\mathrm{AM}$ root colonization, soil organic carbon, soil $\mathrm{pH}$ and available phosphorus. Application of $20 \mathrm{t} \mathrm{ha}^{-1}$ of biochar significantly increased $(\mathrm{P}<0.05)$ soil $\mathrm{pH}$ and available P compared with the control while $10 \mathrm{t} \mathrm{ha}^{-1}$ and $15 \mathrm{t} \mathrm{ha}^{-1}$ of biochar produced higher organic carbon than other rates. In conclusion, biochar increased soil $\mathrm{pH}$ but was not high enough as to have detrimental effect on soil properties. It is, therefore, recommended that biochar with very strongly alkaline $\mathrm{pH}$ should only be used in soil with low $\mathrm{pH}$ for improvement of soil chemical and AM root colonization.
\end{abstract}

Keywords: biochar; AM root colonization; inoculation; chemical properties

\section{Introduction}

Application of biochar to soil have been shown to enhance soil quality [1] and to increase crop yields by improving soil properties such as water and nutrient retention [2], and also increased $\mathrm{pH}$ and $C$ levels [3]. According kolb et al [4], biochar application to soil can change soil nutrients availability by improving soil properties, enhancement of host plant performance and higher colonization rates of the host plant roots by AMF. However, Wallstedt et al [5] reported a contrasting observation that biochar applications did not always benefit soil. For example, biochar application into the soil may decrease the nutrient availability or create unfavourable nutrient ratios in the soils. Gaur et al [6] reported that this adverse effect could be more pronounced when biochar has a very high $\mathrm{C} / \mathrm{N}$ ratio and a portion of the biochar is decomposable or high rate of biochar application leading to $\mathrm{N}$ immobilization. Some reports emphasize that biochar amendments can increase \% AM root colonization in plant roots [7] while others show 
Effect of Biochar Application and Arbuscular Mycorrbizal Inoculation on Root Colonization and Soil Chemical Properties

decrease in AMF abundance [8]. Inhibited colonization after char amendment might be due to improved availability of P [9]. Moreover, Abbott et al [10] reported that mycorrhizal colonization in peanut plants was significantly depressed by adding P. Mycorrhizal fungi are frequently included in soil management activities in crop production, and widely used as soil inoculums additives [11]. Given the above possibilities for negative responses by soil to biochar amendments [12], knowledge of the effects of biochar on AM root colonization and selected soil chemical properties is paramount for environment-friendly functions of AMF in biochar amended soil. This study aims to determine the effect of biochar and AMF inoculation on AM root colonization and selected soil chemical properties.

\section{Materials and Methods}

\subsection{Experimental Site}

The experiment was carried out at the Teaching and Research Farm of the Federal University of Agriculture, Abeokuta, Ogun State, Nigeria, in 2013 / 2014. The area is located between Latitude $7^{\circ} 12^{\prime} \mathrm{N}$ and Longitude $3^{\circ} 20^{\prime} \mathrm{E}$ and lies in the south-western Nigeria in the transitional zone. Daily temperature ranges between $24^{\circ} \mathrm{C}$ and $30^{\circ}$ $\mathrm{C}$ and annual rainfall in the area ranges between $1100 \mathrm{~mm}$ and $1300 \mathrm{~mm}$.

\subsection{Experimental Materials and Design}

The total plot size was $315 \mathrm{~m}^{2}$ with the sub-sub plot size of $2 \mathrm{~m} \times 1 \mathrm{~m}$, a spacing of $1 \mathrm{~m}$ between and within sub-sub plots. The plant spacing was $30 \mathrm{~cm}$ between and within the plant stands consisting of eighteen plants per sub-sub plot. The field layout was split- split plots design with two tomato genotypes in the main plots, five biochar rates of application $\left(0,5,10,15,20 \mathrm{t} \mathrm{h}^{-1}\right)$ in the sub plots and two levels of AMF inoculation (with and without) in the sub-sub plots. The AMF (Glomus mosseae) inoculation was done during the nursery planting at the rate of 80 $\mathrm{g}$ of AMF inoculants per $5 \mathrm{~kg}$ of sterilized top soil while the biochar was applied two weeks before transplanting (WAT). Weeding was done using hoe at 4 and 8 WAT while cypermethrin (insecticide) was applied at 2, 6, and $9 \mathrm{WAT}$ at the rate of $450 \mathrm{ml}$ of active ingredients to 100 liters of water per hectare of land using knapsack sprayer.

\subsection{Soil and Root Sampling}

Soil samples for analyses were taken before planting and after harvest. The rhizosphere soils from three plants in the middle row of each subsub plot along with the roots of tomato plants were dug out at a depth of about $0-20 \mathrm{~cm}$ for $\mathrm{AM}$ root colonization studies. Another set of soil samples from six different points from each subsub plot were collected to evaluate for soil $\mathrm{pH}$, organic carbon and available P. The root samples were stored in 50\% ethanol until processing.

\subsection{Quantification of AM Root Colonization}

Approximately 20 root bits of $1 \mathrm{~cm}$ size were chosen randomly from each sub-sub plot for AM colonization studies following Phillip et al [13] method. The root samples from $50 \%$ ethanol were washed thoroughly and then placed in $10 \%$ $\mathrm{KOH}$ and heated in water bath for 15 minutes and rinsed. The root samples were then stained with a mixture of 1:1:1 of glycerol, lactic acid and distilled water and $0.05 \%$ methyl blue solution and heated for 5 minutes and then rinsed again. Glycerol (50 \%) was added to preserve the root samples and mounted on compound microscope slides for visualizing the fungal structure. Quantification of AM colonization was done based on presence/absence of arbuscules, hyphae or vesicles [14] and percentage of root colonization quantified as follows:

AM root colonization $(\%)$
\[ =\frac{\text { Number of roots colonised }}{\text { Total number of roots examined }} \times 100 \]

\subsection{Laboratory Analysis of the Soils}

Soil $\mathrm{pH}$ was determined in 1:1 soil-water suspension [15], organic carbon by Walkley-Black oxidation method [16], total nitrogen $(\mathrm{N})$ by micro- Kjeldahl distillation method [17], available P by Bray 1 method [18], exchangeable $\mathrm{K}$ and $\mathrm{Na}$ by the flame photometer method, $\mathrm{Ca}$ and $\mathrm{Mg}$ by EDTA titration method [19]. Particle size analysis was done using hydrometer method [20]. The analyses were carried out at Soil Science and Land Management Laboratory, FUNAAB. 
Yusif et al., Int. Ann. Sci.; Vol. 1 Issue 1, pp: 33-38, 2016

\subsection{Data Analysis}

Data obtained from this study were subjected to separate ANOVA using PROC GLM in SAS to compute mean and then separated using Duncan's Multiple Range Test (DMRT) at 5\% level of significance.

\section{Results and Discussions}

\subsection{Physicochemical Characteristics of Soil and Biochar Chemical Characteristics}

The field soil recorded $6.8 \mathrm{pH}$ in $\mathrm{H}_{2} \mathrm{O}$ (1:1), 778 $\mathrm{g} \mathrm{kg}^{-1}$ sand, $134 \mathrm{~g} \mathrm{~kg}^{-1}$ clay, $88 \mathrm{~g} \mathrm{~kg}^{-1}$ silt, $1.48 \%$ OC, $0.21 \% \mathrm{~N}, 10.13 \mathrm{mg} \mathrm{kg}^{-1}$ available $\mathrm{P}, 0.62$ cmol kg-1 K, $0.5 \mathrm{cmol} \mathrm{kg}^{-1} \mathrm{Ca}, 2.9 \mathrm{cmol} \mathrm{kg}^{-1} \mathrm{Mg}$, $0.86 \mathrm{cmol} \mathrm{kg}^{-1} \mathrm{Na}$ (Table 1). The biochar used for this study recorded $10.2 \mathrm{pH}$ in $\mathrm{H}_{2} \mathrm{O}(1: 1), 14.4 \%$ OC, $1.94 \% \mathrm{~N}, 31.00 \mathrm{mg} \mathrm{kg}^{-1}$ total P, $2.29 \% \mathrm{~K}$, $0.022 \% \mathrm{Mg}$, and $0.13 \%$ Fe (Table 2 ).

Table 1: Physicochemical properties of the soil used for this study

\begin{tabular}{|l|c|}
\hline Properties & Soil \\
\hline $\mathrm{pH} \mathrm{H}_{2} \mathrm{O}(1: 1)$ & 6.8 \\
\hline Sand g kg-1 & 778 \\
\hline Clay g kg-1 & 134 \\
\hline Silt g kg-1 & 88 \\
\hline Textural class & Sandy loam \\
\hline $\mathrm{O} C$ \% & 1.48 \\
\hline $\mathrm{N} \mathrm{\%}$ & 0.21 \\
\hline Available P $\left(\mathrm{mg} \mathrm{kg}^{-1}\right)$ & 10.13 \\
\hline Exchangeable Bases $\left(\mathbf{c m o l}^{-1} \mathbf{~ g g}^{-1}\right)$ \\
\hline $\mathrm{K}$ & 0.62 \\
\hline $\mathrm{Ca}$ & 0.5 \\
\hline $\mathrm{Mg}$ & 2.9 \\
\hline $\mathrm{Na}$ & 0.86 \\
\hline
\end{tabular}

Table 2: Chemical composition of biochar used for

\begin{tabular}{|c|c|}
\hline \multicolumn{2}{|c|}{ this study. } \\
\hline PARAMETERS & BIOCHAR \\
\hline $\mathrm{pH} \mathrm{H}_{2} \mathrm{O}(1: 1)$ & 10.12 \\
\hline $\mathrm{O} \mathrm{C} \%$ & 14.4 \\
\hline $\mathrm{N} \%$ & 1.94 \\
\hline Total P $\left(\mathrm{mgkg}^{-1}\right)$ & 31.00 \\
\hline $\mathrm{K} \%$ & 2.29 \\
\hline $\mathrm{Mg} \%$ & 0.022 \\
\hline $\mathrm{Fe} \%$ & 0.13 \\
\hline
\end{tabular}

\subsection{Mycorrhizal Effect on AM Root Colonization, Soil pH, Organic Carbon and Available $P$}

The results from this study showed that mycorrhizal inoculation in biochar amended soil had little or no contribution to AM root colonization (Table 3), soil $\mathrm{pH}$, organic carbon and available $\mathrm{P}$ as shown in Table 4.

Table 3: Effects of genotype, biochar and AMF inoculation on AM root colonization of tomato

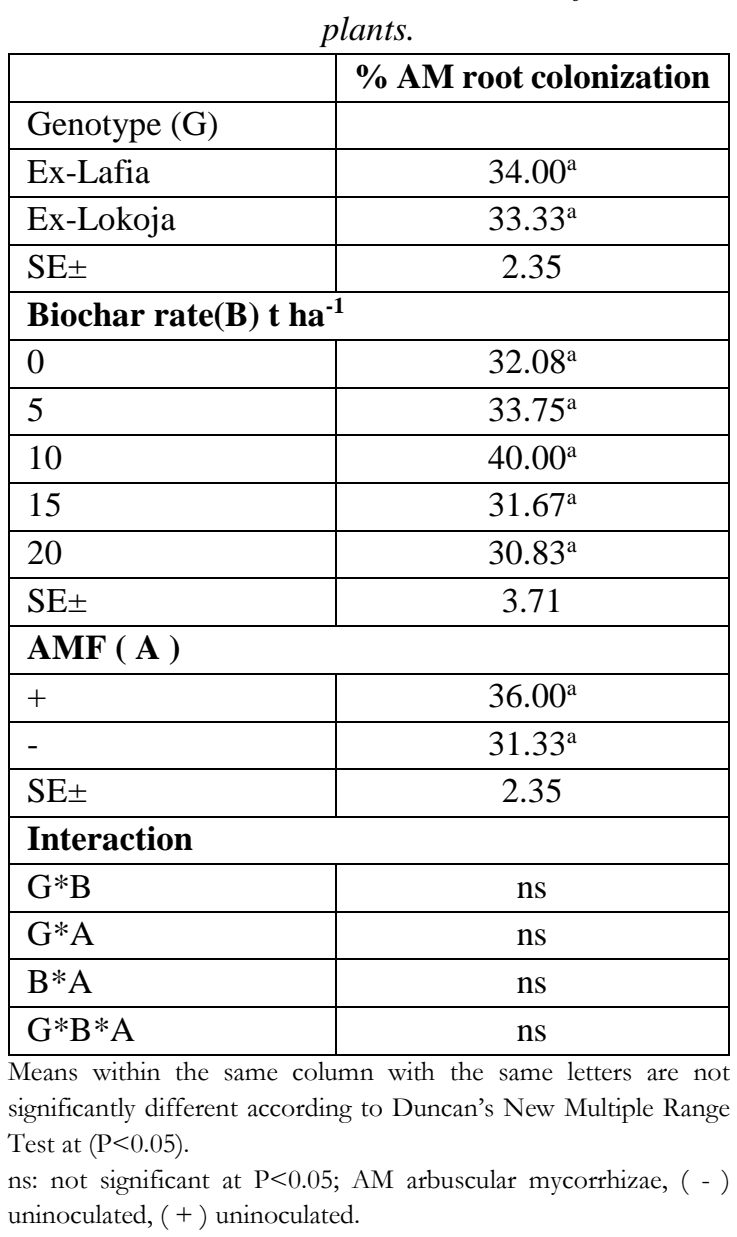

However, non-mycorrhizal plots had higher values of organic carbon. Non-significant effect of mycorrhiza on root colonization was reported by Osonubi et al [21] who found no increase in AM colonization on the field since even uninoculated plot have some indigenous mycorrhiza. Abbott et al [10] also reported that mycorrhizal colonization in peanut plants was significantly depressed by adding P. Sanchez et al [22] related the reduction in the AM root colonization, and functionality of AMF towards nutrient availability probably to high soil fertility 
Effect of Biochar Application and Arbuscular Mycorrbizal Inoculation on Root Colonization and Soil Chemical Properties

level, which reduced the dependence of the plants on mycorrhizae and therefore restricted the development of these fungi to the root cortex. Since non-mycorrhizal plots were assumed to have less number of mycorrhizal organisms, then, low utilization of organic carbon is expected compared to mycorrhizal plots. This suggests that there was biologically active $\mathrm{C}$ in the biochars, which was utilized by soil microorganisms as an energy source [23].

\subsection{Biochar Effect on AM Root Colonization, Soil pH, Organic Carbon and Available $\mathbf{P}$}

Biochar application didn't influence any increased in AM root colonization as given in Table 3. This agrees with reports by Warnock et al [8] who found decrease in AMF abundance due to biochar amendment. Inhibited colonization after biochar amendment might be due to improved availability of P [9]. Moreover, Abbott et al [10] reported that mycorrhizal colonization in peanut plants was significantly depressed by adding P. Soil $\mathrm{pH}$ was significantly $(\mathrm{P}<0.05)$ higher with $15 \mathrm{t} \mathrm{ha}^{-1}$ and $20 \mathrm{tha}^{-1}$ followed by 10 $\mathrm{t} \mathrm{ha} \mathrm{a}^{-1}$ and then $5 \mathrm{t} \mathrm{ha}^{-1}$ and lastly by $0 \mathrm{t} \mathrm{ha}^{-1}$ of biochar rates as given in Table 4 . The $20 \mathrm{t} \mathrm{ha}^{-1}$ of biochar produced significantly $(\mathrm{P}<0.05)$ higher available $\mathrm{P}$ while $15 \mathrm{t} \mathrm{ha}^{-1}$ produced higher soil organic carbon when compared with control as given in Table 4. Increase in soil $\mathrm{pH}$, organic carbon and available $\mathrm{P}$ in soils treated with increasingly larger quantities of biochar were observed [8; 24; 25]. Soil $\mathrm{pH}$ as given in Table 4 and shown in Figure 1 and available P (Table 4) were increased with increase in biochar application rates with little or no influence by mycorrhizal inoculation. This could be attributed to the very strongly alkaline $\mathrm{pH}$ of the maize cob biochar and the tendency to raise soil $\mathrm{pH}$ was certain. Meanwhile, high organic carbon obtained could be attributed to high organic carbon in the maize-cob biochar [26; 27]. Available $\mathrm{P}$ was also higher with biochar application rates and attributed to higher amounts of total $\mathrm{P}$ in the maize cob and high $\mathrm{pH}$ that could help in breaking the bond of $\mathrm{Al}$ and $\mathrm{Fe}$ complexes with $\mathrm{P}$ in the soil thereby releasing more $\mathrm{P}$ into soil solution $[28 ; 29]$. No significant interaction was observed among genotype, biochar and AMF in
AM root colonization (Table 3). Significant interaction was observed between biochar and AMF and between genotype and AMF in soil $\mathrm{pH}$ and available $\mathrm{P}$ respectively (Table 4$)$.

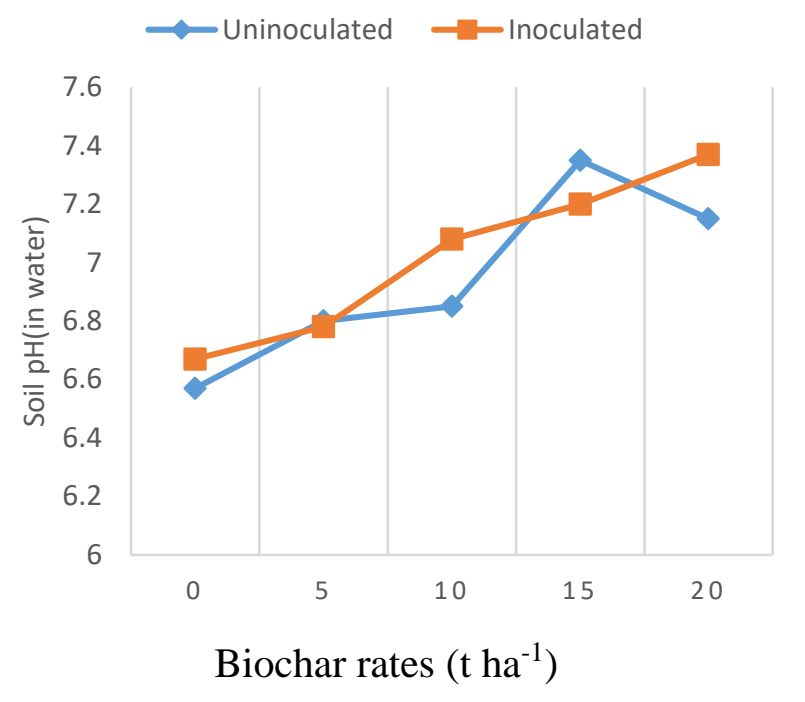

Figure 1: Soil $p H$ as affected by the interaction of biochar rates and AMF inoculation in the field

Table 4: Effects of genotype, biochar and AMF inoculation on soil chemical properties.

\begin{tabular}{|c|c|c|c|}
\hline & $\begin{array}{l}\text { Soil } \\
\mathrm{pH} \mathrm{H}_{2} \mathrm{O}\end{array}$ & $\% \mathrm{OC}$ & $\begin{array}{l}\text { Available } \\
\left.\text { P (mg kg}{ }^{1}\right)\end{array}$ \\
\hline \multicolumn{4}{|c|}{ Genotype (G) } \\
\hline Ex-Lafia & $7.02^{\mathrm{a}}$ & $1.26^{\mathrm{b}}$ & $11.82^{\mathrm{a}}$ \\
\hline Ex-Lokoja & $6.95^{\mathrm{a}}$ & $1.61^{\mathrm{a}}$ & $12.52^{\mathrm{a}}$ \\
\hline $\mathrm{SE} \pm$ & 0.03 & 0.04 & 0.46 \\
\hline \multicolumn{4}{|c|}{ Biochar rate(B) t ha-1 } \\
\hline 0 & $6.62^{\mathrm{d}}$ & $1.29^{\mathrm{b}}$ & $10.93^{b}$ \\
\hline 5 & $6.79^{c}$ & $1.34^{\mathrm{ab}}$ & $12.19^{\mathrm{ab}}$ \\
\hline 10 & $6.97^{\mathrm{b}}$ & $1.54^{\mathrm{a}}$ & $10.87^{\mathrm{b}}$ \\
\hline 15 & $7.28^{\mathrm{a}}$ & $1.53^{\mathrm{a}}$ & $13.05^{\mathrm{ab}}$ \\
\hline 20 & $7.26^{\mathrm{a}}$ & $1.45^{\mathrm{ab}}$ & $13.83^{\mathrm{a}}$ \\
\hline $\mathrm{SE} \pm$ & 0.04 & 0.06 & 0.72 \\
\hline \multicolumn{4}{|l|}{$\operatorname{AMF}(\mathbf{A})$} \\
\hline+ & $7.02^{\mathrm{a}}$ & $1.33^{\mathrm{b}}$ & $12.08^{\mathrm{a}}$ \\
\hline- & $6.94^{\mathrm{a}}$ & $1.53^{\mathrm{a}}$ & $12.27^{\mathrm{a}}$ \\
\hline $\mathrm{SE} \pm$ & 0.03 & 0.04 & 0.46 \\
\hline \multicolumn{4}{|l|}{ Interaction } \\
\hline $\mathrm{G}^{*} \mathrm{~B}$ & $\mathrm{~ns}$ & ns & $\mathrm{ns}$ \\
\hline $\mathrm{G}^{*} \mathrm{~A}$ & $\mathrm{~ns}$ & ns & $*$ \\
\hline $\mathrm{B} * \mathrm{~A}$ & $*$ & $\mathrm{~ns}$ & ns \\
\hline $\mathrm{G}^{*} \mathrm{~B} * \mathrm{~A}$ & ns & ns & ns \\
\hline \multicolumn{4}{|c|}{$\begin{array}{l}\text { Means within the same column with the same letters are not } \\
\text { significantly different according to Duncan's New Multiple Range } \\
\text { Test at }(\mathrm{P}<0.05) \text {. } \\
\text { ns: not significant at } \mathrm{P}<0.05 \text {. ( - ) uninoculated, }(+) \text { uninoculated, } \\
\text { OC = Organic carbon, } \mathrm{P}=\text { Phosphorous. }\end{array}$} \\
\hline
\end{tabular}


Yusif et al., Int. Ann. Sci.; Vol. 1 Issue 1, pp: 33-38, 2016

\section{Conclusions}

Biochar application remarkably improved soil organic carbon, soil $\mathrm{pH}$ and available $\mathrm{P}$. However, the increase in soil $\mathrm{pH}$ was not high enough as to have detrimental effect on soil properties. Mycorrhizal inoculation showed little or no effect on AM root colonization, soil organic carbon, soil $\mathrm{pH}$, and available P. It is, therefore, recommended that biochar with very strongly alkaline $\mathrm{pH}$ should be used only in soil with low $\mathrm{pH}$ for improvement of soil chemical and $\mathrm{AM}$ root colonization.

\section{How to Cite this Article:}

S. Yusif and M. Dare, "Effect of Biochar Application and Arbuscular Mycorrhizal Inoculation on Root Colonization and Soil Chemical Properties", International Annals of Science, vol. 1, no. 1, pp. 33-38, 2016. doi: 10.21467/ias.1.1.33-38

\section{References}

[1] S. Sohi, E. Lopez-Capel, E. Krull, and R. Bol, "Biochar, climate change and soil: A review to guide future research", CSIRO Land and Water Science Report, vol. 5, no. 9, pp.17-31, 2009.

[2] C. Steiner, W.G. Teixeira, J. Lehmann, T. Nehls, J.L. Vasconcelos de Macedo, W.E.H. Blum, and W. Zech, "Long term effects of manure, charcoal and mineral fertilization on crop production and fertility on a highly weathered Central Amazonian upland soil" Plant Soil, 2007.

[3] K. Chan, L. Van Zwieten, I. Meszaros, A. Downie, and S. Joseph, "Using poultry litter biochars as soil amendments", Soil Research, vol. 46, no. 5, pp. 437-44, 2008.

[4] S.E. Kolb, K.J. Fermanich, and M.E. Dornbush, "Effect of charcoal quantity on microbial biomass and activity in temperate soils", Soil Biology and Biochemistry, vol. 73, pp. 1173-1181, 2009.

[5] A. Wallstedt, A. Coughlan, A.D. Munson, M.C. Nilsson, and H. A. Margolis, "Mechanisms of interaction between Kalmia angustifolia cover and Picea mariana seedlings", Canadian Journal of Forest Research, vol. 32, pp. 2022-2031, 2002.

[6] A. Gaur, and A. Adholeya, "Effects of the particle size of soilless substrates upon AM fungus inoculum production" Mycorrhiza, vol. 10, pp. 43-48, 2000.

[7] W.H. Elmer, and J.J. Pignatello, "Effect of biochar amendments on mycorrhizal associations and Fusarium crown and root rot of asparagus in replant soils", Plant Disease, vol. 95, no. 8, pp. 960-6, 2011.

[8] D.D. Warnock, D.L. Mummey, B. McBride, J. Major, J. Lehman, and M.C. Rillig, "Influence of nonherbacous biochar on AMF, dormancies in roots and soils, Results from growth chamber and field experiments", Applied Soil Ecology, vol. 462, pp. 450 456, 2010.

[9] D.D. Warnock, J. Lehmann, T.W. Kuyper, and M.C. Rillig, "Mycorrhizal responses to biochar in soil- concepts and mechanisms", Plant and Soil, vol. 300, no.1, pp. 9-20, 2007.

[10] L.K. Abbott, and A.D. Robson, "Field management of VA mycorrhizal fungi", In: D.L. Keister and P.B. Cregan (eds) The Rhizosphere and Plant Growth, Kluwer Academic Publishers, Dordrecht, pp. 355-362, 1991.

[11] M.W. Schwartz, J.D. Hoeksema, C.A. Gehring, N.C. Johnson, J.N. Klironomos, L.K. Abbott, and A. Pringle, "The promise and potential consequences of the global transport of mycorrhizal fungal inoculums", Ecology Letters, vol. 9, pp. 501-515, 2006.

[12] N.C. Johnson, "Can fertilization of soil select less mutualistic mycorrhizae?", Ecological Applications, vol. 3, pp. 749-757, 1993.

[13] J. Phillip, and D. Hayman, "Improved procedure for clearing roots and staining parasitic and vesiculararbuscular mycorrhizal fungi for rapid assessment of infection", Transactions of the British Mycological Society, vol. 55, no.1, pp.158-61, 1970.

[14] T.P. McGonigle, D.G. Evans, and M.H. Miller, "Effect of degree of soil disturbance on mycorrhizal colonization and phosphorus absorption by maize in growth chamber and field experiments", New Phytologist, vol. 116, pp. 629-636, 1990.

[15] R.C. Bates, Electrometric $p H$ determination, John Wiley and Sons Inc, New York. pp. 35-38, 1954.

[16] A.S.R Juo, Selected methods of soil and plant analysis, IITA Manual series no. 1, pp. 70, 1979.

[17] M.L Jackson, Soil chemical analysis. IITA Manual series no. 1, pp. 70, 1962.

[18] R. Bray, and L.T. Kurtz, "Determination of total, organic and available forms of phosphorus in soil", Soil Science, vol. 59, pp. 39-45, 1966.

[19] G.W Gee, and J.W. Baner, 1986. Particle size analysis In: Aklate (ed) Method of Soil Analysis $2^{\text {nd }}$ ed. No. 9 ASA, Inc, SSA Madson, Washington D.C. pp. 383-409.

[20] G.S. Bouyoucos, "Hydrometer method improved for making particle size analysis of soils", Agronomy Journal, vol. 54, pp. 464-465, 1962.

[21] O. Osonubi, K. Mulongoy, O.O. Awotoye, M.O. Ateyese, and D.U. Okali, "Effects of ectomycorrhiza and VAM fungi on drought tolerance of four leguminous woody seedlings", Plant and Soil, vol. 136, pp. 131-143, 1991.

[22] P.A. Sanchez, and J.G. Salinas, "Low input technology for managing Oxisols and Ultisols in tropical America", Advances in Agronomy, vol. 34, 279-406, 1981.

[23] R.C. Unger, "The effect of biochar on soil properties and corn grain yields in Iowa", Masters Thesis, IowaState University, Ames, Iowa, Paper 117119, 2008.

[24] M. Yamato, Y. Okimori, I.F. Wibowo, S. Anshiori, and M. Ogawa, "Effects of the application of charred bark of Acacia mangium on the yield of maize, cowpea and peanut, and soil chemical properties in South Sumatra, Indonesia", Soil Science and Plant Nutrition vol. 52, pp. 489-495, 2006.

[25] S.A. Yusif, I. Muhammad, N.G. Hayatu, M. Haliru, M.A. Mohammed, A.M. Hussain, and A.Y. Fardami, "Effects of Biochar and Rhizobium Inoculation on Selected Soil Chemical Properties, Shoot Nitrogen and Phosphorus of Groundnut Plants (Arachis hypogaea L.) in Sokoto State, Nigeria. Journal of Advances in Biology and Biotechnology, vol. 8, no. 2, pp. 1-6, 2016. 
Effect of Biochar Application and Arbuscular Mycorrbizal Inoculation on Root Colonization and Soil Chemical Properties

[26] J. Lehmann, "Bio-energy in the black", Frontiers in Ecology and the Environment, vol. 5, pp. 381-387, 2007.

[27] D. Solomon, J. Lehmann, J. Thies, T. Schafer, B. Liang, J. Kinyangi, E. Neves, J. Petersen, F. Luizo, and J. Skjemstad, "Molecular signature and sources of biochemical recalcitrance of organic $\mathrm{C}$ in Amazonian dark earths", Geochimica et Cosmochimica Acta, vol. 71, pp. 2285-2298, 2007.

[28] A. Nigussuie, E. Risson, M. Misganaw, and G. Anbanss, "Effect of biochar application on soil properties and nutrient uptake of lethieo (Lactuca sation) grown in chromium polluted soils", American Eurasian Journal of Agricultural and Environmental Sciences, vol. 12, no. 3, pp. 369-375, 2012.

[29] L. Van Zwieten, S. Kimber, S. Morris, A. Downie, E. Berger, J. Rust, and C. Scheer, "Influence of biochars on flux of $\mathrm{N}_{2} \mathrm{O}$ and $\mathrm{CO}_{2}$ from Ferrosol", Australian Journal of Soil Research, vol. 48, pp. 555-568, 2010.

\section{Publish your research article in AIJR journals- \\ $\checkmark$ Online Submission and Tracking \\ $\checkmark$ Peer-Reviewed \\ $\checkmark$ Rapid decision \\ $\checkmark$ Immediate Publication after acceptance \\ $\checkmark$ Articles freely available online \\ $\checkmark$ Retain full copyright of your article. \\ Submit your article at journals.aijr.in}

Publish your books with AIJR publisher-

$\checkmark$ Publish with ISBN and DOI.

$\checkmark$ Publish Thesis/Dissertation as Monograph.

$\checkmark$ Publish Book Monograph.

$\checkmark$ Publish Edited Volume/ Book.

$\checkmark$ Publish Conference Proceedings

$\checkmark$ Retain full copyright of your books.

Submit your manuscript at books.aijr.org 